\title{
New evidence on the pricing and performance of initial public offerings in Thailand, 1997-2008
}

\author{
Jirapun Chorruk ${ }^{\mathrm{a}}$ Andrew C. Worthington ${ }^{\mathrm{b}, *}$ \\ ${ }^{a}$ Mahasarakham University, Thailand \\ ${ }^{b}$ Griffith University, Australia
}

\begin{abstract}
This paper examines the pricing and performance of initial public offerings (IPOs) on the Stock Exchange of Thailand (SET) from 1997 to 2008. Underpricing is calculated using headline underpricing and underpricing issuer loss, loss by market value, and loss by issuer price. The results show underpricing of $17.60 \%, 5.01 \%, 6.94 \%, 6.68 \%$ and $16.10 \%$, respectively. This is significantly lower underpricing than documented in Thailand before the 1997 Asian financial crisis. Post-listing performance is assessed using monthly cumulative abnormal returns, buy-and-hold returns, and wealth relatives. The findings show that Thai IPOs generally outperform market benchmarks up to 24 months and underperform thereafter.
\end{abstract}

JEL classification: C12; C23; G24; G32

Keywords: initial public offerings; pricing; abnormal returns; Stock Exchange of Thailand

\footnotetext{
* Corresponding author. Department of Accounting, Finance and Economics, Griffith University, 170 Kessels Road, Nathan QLD 4111, Australia. Tel.: +61 73735 4273; fax: +61 737353719.

E-mail address: a.worthington@griffith.edu.au (Andrew C. Worthington).
} 



\section{Introduction}

From record highs (in both deals and capital raised) in the fourth quarter of 2007 the global initial public offering (IPO) market has experienced successive dramatic declines and now lies at its lowest level in more than a decade. However, despite experiencing parallel impacts to developed markets in the aftermath of the global financial crisis, emerging markets are continuing to drive what little activity remains in the global IPO market. For example, in the March 2009 quarter, developing economies made up 68\% of the number of deals globally (albeit with only 33\% of total capital raised) compared to developed economies, and six of the top ten IPOs and 12 of the top 20 IPOs by capital raised were from emerging markets. Of these, the Asia-Pacific was the leading region with a 72\% market share with the Far East (South Korea, Japan, China/Hong Kong, Thailand, Singapore and Vietnam) accounting for the majority (Ernst and Young 2009).

It is likely that the outcomes generated by the current economic situation will provide a similar watershed for emerging markets as the 1997 Asian financial crisis, of which Thailand represents an interesting case. From humble beginnings in 1975, the Stock Exchange of Thailand (SET) (2009a) experienced moderate IPO growth in its start-up phase until 1987. From then until 1997, IPOs grew strongly in a period of rapid expansion, at which time the market entered a period of maturity and stabilisation. By 2006, Thailand ranked highest in South-East Asia for total capital raised and the total number of completed IPOs (before Malaysia, Singapore, the Philippines, and Indonesia) and sixth in the Asia-Pacific (after China, Japan, India, South Korea and Australia (Ernst and Young 2006).

However, there is considerable uncertainty in the current outlook, with both internal and external factors severely affecting the Thai capital market. In the first half of 2008, the global financial and oil price crises, and internal political instability negatively affected the capital market, with the Bank of Thailand failing to adequately stimulate the market. In the second half of 2008, the subprime loan crisis caused many local financial institutions to face a liquidity crisis with a flow on to other sectors. In response, foreign investors have repatriated funds to meet margin calls and fund redemptions, with foreign investors in Thailand now effectively net sellers (SET 2009b). Overall, and in little more than a year, the SET has fallen by more than 40 percent in market capitalisation, dividend yields have doubled and price-earnings 
ratios halved, and local investors are accounting for an increasing share of turnover. It is therefore an opportune time to reflect on the most recent IPO development phase in this regionally important emerging market.

Unfortunately, although a substantial amount of research of this type exists in the United States and elsewhere, and even some in emerging markets (Bruner et al., 2006; Chang et al., 2008), Thai studies concerning important aspects of IPOs, especially pricing and performance, are scarce and limited in scope. This paper's principal objective is then to increase the depth of Thai research by examining the pricing and performance of initial public offers during the period 1997 to 2007. This is important research in emerging market terms because it provides a long-run perspective on pricing and performance, and thus enables us to ascertain with some confidence whether these increasingly globally important markets display different behaviour to that found in developed markets.

The paper is organized as follows. Section 2 discusses the Thai IPO market. Section 3 provides a brief literature review. Section 4 explains the methodology and Section 5 presents the empirical results. Section 6 contains some brief concluding remarks.

\section{Thai IPO Market}

The Thai equity market, as elsewhere, comprises a primary market and a secondary market. The primary market is where IPOs and subsequent issues are first made available to the public and lies under the supervision of the Thai Securities and Exchange Commission (SEC) (2009). A company wishing to issue an IPO must first apply to the SEC for approval and satisfy its filing requirements prior to it allowing the company to list and trade. However, in contrast to many other national markets, there are two primary markets in Thailand: the Stock Exchange of Thailand (SET) (2009a) and the Market for Alternative Investments (mai) (2009). The SET is the main board for large public limited companies with at least 300 million baht (USD1 = THB35) of paid-up capital (SET 2008), while IPOs for small-and-medium-sized enterprises (SMEs) with paid-up capital between 20 and 300 million baht are generally able to list on the mai (mai 2008).

The SET was established in 1961 as an outcome of the Thai government's fiveyear National Economic and Social Development plan. The objective of this plan was to support the economic growth and stability of the country, in addition to developing 
a higher standard of living. When the basic legislative framework was in place, the SET officially commenced trading on April 30, 1975. Since then, the SET has grown significantly in size and trading activities, with the total number of listed companies increasing from 21 in 1975 to 475 in 2007. Securities traded on the SET include common stock, preferred stock, depository receipts, unit trusts, warrants, derivative warrants and transferable subscription rights. Trading of common stocks, however, dominates all other securities. By the end of 2007, the number of common stock issues had grown to 491 alongside 10 issues of preferred stock, 1 depository receipt, 8 unit trusts, and 71 warrants of various types; a total of 581 individual securities. The market value of trading reached 6,636,068.73 million baht with a daily average of 17,097.05 million baht over this same period. Currently, the SET is the fourteenthlargest market in the Asia-Pacific by capitalisation, thirteenth-largest in terms of the number of listed companies, and twelfth-fastest by turnover velocity (WFE 2007).

\section{$<$ FIGURE 1 HERE $>$}

As shown in Figure 1, past IPO activity in Thailand can be readily divided into three periods: (i) the period from 1975 to 1986; (ii) a period of rapid economic growth from 1987 to 1996; and (iii) a period of 'crisis' and 'post crisis' from 1997 to the present (Lonkani and Firth, 2005). During the first period, few IPOs were listed on the market. From 1987 to 1996, Thailand enjoyed rapid economic growth and many firms used the stock market as a major source for external funding. The third period began with the Asian financial crisis that started in July 1997. The effects of the crisis and its aftermath linger today and, as a result, the numbers of IPOs remain below the levels set in the late 1980s and the early and mid-1990s.

During the first period, 103 IPOs were listing at an average rate of nine IPOs per year. However, the number of IPOs began to grow rapidly during the second period with 376 issues (or an average of 38 IPOs per year) by some 280 listed companies (an increase of 251.32 percent). By the third period, the number of total listed companies had increased by approximately 425.09 percent from when the SET was established. During this time, only 200 IPOs were listed or just 18 IPOs per year. Nevertheless, since 1975 the total number of listed companies in the SET has increased on average by about 15 companies per year. 


\section{Review of the literature}

One of the more puzzling (and important) phenomena in finance is the underpricing of new stock issues. Various explanations are given, including information asymmetry, signalling relationships, cyclical behaviour and third-party certification. Foremost among these, the information asymmetry hypothesis sees underpricing as an equilibrium occurrence when investors are disproportionately informed. As uninformed investors face the consequences of poor judgement when other investors are better informed, underpricing arises to compensate uninformed investors for the risk of ending up with a less successful IPO.

Underpricing is clearly a concern for entrepreneurs, venture capitalists and private equity investors as it reduces the amount received by going public. However, one argument is that the extent of the entrepreneurs' concerns is limited to the influence on their net wealth. Costly action, such as employing reputable underwriters, is undertaken only where advantageous. In general, as the proportion of the company going public escalates, the existing investors in the firm attempt to reduce underpricing at an increasing rate. When informed investors believe an issue is overpriced, they discard the investment opportunity and seek issues elsewhere that are not overpriced.

An alternative rationale for underpricing is that the value of an issue depends on market demand and the underwriter's selling efforts. In general, the underwriter is typically aware of demand levels, more so than the issuer. As such, the issue price is set below its 'true value' to increase interest. Similarly, the issuer is more informed then potential investors. In an attempt to resolve problems with asymmetric information, the underwriter signals the true value of the firm by underpricing the securities and acquires a percentage of the shares. The retention of shares comes as a signalling device to the market - the higher the withholding, the higher the return expected.

Other work draws attention to the signalling relationship between the issuer's fractional holding of the firm's equity and the expected future cash flows. In response to these and other theoretical developments, a body of empirical research has arisen, largely in the US, concluding that IPOs are indeed underpriced [see, most recently, Ibbotson et al. (1994), Megginson and Weiss (1991), Hunt-McCool et al. (1996), 
Habib and Ljungqvist (1998; 2001), Francis and Hasan (2001), Bradley and Jordan (2002), Loughran and Ritter (1995; 2002)].

Relatively fewer studies concern IPO (under)pricing in Thailand, with all extant work focusing on the pre-1997 Asian financial crisis period [Wethyavivorn and KooSmith (1991), Allen et al. (1999), Lonkani (2000) and Lonkani and Firth (2005)]. For example, Wethayavivorn and Koo-Smith (1991) studied 32 IPOs over the period 1988-1989 and found that the average initial return was 56.73\%. Similarly, using a sample of 150 IPOs from 1985 to 1992, Allen et al. (1999) reported that the average initial return for Thai IPOs was 63.49 percent, while Lonkani (2000) concluded that the average initial return was 46.70 percent using a sample of 292 IPOs from 1987 to 1997. Generally, and in common with evidence from developed markets, these studies provide evidence that IPOs in Thailand are also substantially underpriced.

Unfortunately, previous IPO studies in Thailand do suffer from a number of limitations. First, they usually concern the period before the 1997 Asian financial crisis. That is, the period from 1975 to 1986 corresponding to the start-up of the SET and/or the period of rapid economic growth from 1987 to 1996. No known study concerns the increasing maturity of the SET IPO market found since 1997, as analysed in this paper. Second, previous studies employ only a single measure of underpricing, unlike the present analysis that employs five distinct measures that allow for the returns to existing owners, strategic shareholders, and primary and secondary shareholders. Combined together, these measures permit a better understanding of the impact of underpricing upon the parties most involved and affected by the IPO process.

In terms of performance, most of the extant work concurs with work in the US by Moonchul and Ritter (1999) that post-IPO firms generally underperform as investors are overly optimistic about their potential when listed. However, Loughran and Ritter (1995) counter that underperformance is not a unique trait of IPOs, rather a result of IPO firms being small with low book-to-market values. Once again, there are just a few recent studies of Thai IPO performance, including Allen et al. (1999) and Kim et al (2004). Allen et al (1999), for instance, studied 150 IPO listed on the SET from 1985 to 1992 and uncovered evidence of poor short-run aftermarket performance: the average market-adjusted cumulative abnormal return at the end of the listing month was -2.9 percent $(t$-value $=2.18)$. Nevertheless, they found no evidence for poor long-run performance up to 36 months after the IPO (with the 
exception of the first two months). Indeed, the average market-adjusted cumulative abnormal return at the end of a 36-month period is 10.02 percent, though not statistically significant.

However, when outliers are removed from cross-sectional analysis, there is still the suggestion that Thai IPOs may underperform on average in the long run. Moreover, aftermarket returns are higher with value-weighted adjustment of the benchmark suggesting that smaller firms have better performance. Once again, the aftermarket performance of Thai IPOs is similar to Wethyavivorn and Koo-smith (1991) but contrasts with Ritter (1991), Levis (1993), Aggarwal et al. (1993) and Allen and Patrick (1994). Most recently, Kim et al. (2004) provide evidence of a longterm decline of operating performance for IPO firms in Thailand using a sample of 133 SET IPOs from 1987 to 1993. Once again, existing work on post-listing IPO performance in Thailand suffers from a number of deficiencies. Putting aside the lack of currency in these studies, as discussed earlier, they invariable employ only one or two measures of performance. In contrast, the present analysis conducts comparisons of post-listing performance of Thai IPOs using three measures: namely, cumulative abnormal returns, buy-and-hold returns, and wealth relatives.

\section{Methodology}

A review of the extant literature on the pricing and performance of IPOs suggests two broad hypotheses. First, Thai IPOs are underpriced. Second, Thai IPOs underperform post-listing. In order to test the first set of hypotheses, four complementary measures of underpricing are calculated: headline underpricing, underpricing issuer loss, underpricing loss by market value, and underpricing loss by issue price (Habib and Ljungqvist, 1998; Silva Rosa et al., 2003). To test the second set of hypotheses, monthly average cumulative abnormal returns (CAR), buy-and-hold returns (BHR) and wealth relatives (WR) are calculated. We also employ multivariate regressions to examine aftermarket performance (Ritter 1991; Loughran and Ritter 1995).

\subsection{Sample selection and data sources}

The sample comprises 136 IPOs listed on the SET from February 1997 to November 2007. This compares favourably with the population of 145 IPOs during this period; we excluded nine listings from the sample because of incomplete data. 
Observations on the issue and first day closing prices are from the SETSMART (SET Market Analysis and Reporting Tool). This web-based application from the SET seamlessly integrates the various sources of Thai listed company data, including historical stock prices, indices, listed company profiles and news. Details of the distribution of the IPO (number of primary and secondary shares and total shares) are from the official prospectus filing form (Form 69-1) available on the IPO filing database provided by the Capital Market Information Centre at the SEC.

Other information is from the SET Fact Book series 1997-2007. The proportion of free float and strategic shareholders (the proportion of shares retained by the firm) are from the Information and Communication Technology Department at the SEC. For the performance assessment, the sample comprises 142 IPOs of total 145 newly listed on the SET from February 1997 to November 2007; three listings excluded from the sample because of incomplete data. Data on issue prices, first month closing prices, monthly stock prices, and the SET index are also from SETSMART. We use these to compute the aftermarket performance of Thai IPOs from February 1997 to October 2008.

\subsection{Measures of underpricing}

The four underpricing measures used in this study are adapted from Habib and Ljungqvist (1999) and Silva Rosa et al. (2003). First, headline underpricing (UPH) is a traditional measure of underpricing:

$$
U P H=\frac{\left(P_{c}-P_{i}\right)}{P_{i}}
$$

where $P_{c}$ is the closing price on the first day of trading and $P_{i}$ is the issue price of the company $i$. Second, underpricing issuer loss (UPIL) determines the loss to the issuer per share:

$$
U P I L=(1-\text { Strategic Shareholders }) \times \frac{\left(P_{c}-P_{i}\right)}{P_{i}}
$$

where strategic shareholders is the portion of ownership of the firm retained or the proportion of shares held by the shareholders for the purpose of company management or business strategy and all other variables are as previously defined. Strategic shareholders are equal to $100 \%$ minus the percentage in the free float. Free float is the proportion of shares not held by strategic shareholders and not reacquired 
by the issuing company. This is estimated from the company's shareholder register as of the latest registered book-closing date for the general meeting in each year and is adjusted for subsequent changes in ownership structure.

Third, underpricing loss by market value (UPLMV) is the underpricing loss standardised by the firm's market value:

$U P L M V=\frac{\left(P_{c}-P_{i}\right) \times(\text { Secondary shares }+ \text { Strategic shareholders } \times \text { Primary shares })}{P_{c} \times \text { Total shares }}$

where secondary shares are the number of shares held by pre-IPO shareholders, primary shares are the number of new shares offered in the IPO and total shares are the total shares on issue for the post-IPO firm. Finally, the underpricing loss by issue price (UPLIP) shows the loss to the issuer standardized by the value of the firm based on the issue price.

$U P L I P=\frac{\left(P_{c}-P_{i}\right) \times(\text { Secondary shares }+ \text { Strategic shareholders } \times \text { Primary shares })}{P_{i} \times \text { Total shares }}$

We calculate the four underpricing measures in Equations (1)-(4) for each firm in the sample and compile the mean and median values. Finally, we calculate a valueweighted measure of each underpricing measure using:

$$
\sum_{i}\left(\text { Total shares }_{i} \times U P_{i}\right) / \sum_{i} \text { Total shares }_{i}
$$

where $U P_{i}$ is UPSTD, UPIL, UPLMV and UPLIP, respectively. This measure of underpricing takes into account a firm's size relative to the level of underpricing.

\subsection{Measures of aftermarket performance}

The methodology used to measure IPO performance follows Ritter (1991), Brav and Gromper (1997) and Lyon et al. (1999) in the compilation of monthly (1) cumulative abnormal (CARs) (2) buy-and-hold returns (BHRs) and (3) wealth relatives (WRs). The assumptions and purposes of these alternative measures of performance vary. First, CARs are a traditional performance measure calculated as the accumulated differences between the average initial return and the average benchmark return. Second, BHRs reflect the returns on a strategy of investing in an average sample company and deducting the return on a corresponding benchmark (market, industry, sector index) over the investment horizon. For instance, Barber and 
Lyon (1997) and Lyon et al. (1999) argue that the investor experience is better captured by compounding short-term returns (for example, at monthly intervals) to obtain the long-term holding period abnormal return. Finally, WRs provide an overall indicator of long-term performance by calculating the ratio of the end-of-period wealth from a portfolio of issuers to the end-of-period wealth from a portfolio of market benchmarks.

\section{Cumulative abnormal returns (CARs)}

The CARs are calculated in the following manner. First, the raw return for company $i$ for event month $t$ is measured as:

$$
R_{i t}=\frac{\left(P_{c}-P_{i}\right)}{P_{i}}
$$

where $R_{i t}$ is the monthly raw return for company $i$ in event month $t$ where the starting price for each company is its last price for the month of listing, excluding the initial return, $P_{c}$ is the closing price on the first month of listing, and $P_{i}$ is the issue price of company $i$. We first calculate the monthly raw return from months 1 to 36 or until delisting for each company. The event month is the month following the listing month. Second, benchmark returns for company $i$ is calculated in the same way as the raw return as follows:

$$
R_{\text {bencht }}=\frac{\left(P_{c-\text { bench }}-P_{i-b e n c h}\right)}{P_{i-b e n c h}}
$$

where $R_{\text {bencht }}$ is the monthly benchmark return on company $i, P_{c-b e n c h}$ is the closing price of the benchmark on the first listing month and $P_{i-b e n c h}$ is the closing price of the benchmark on the previous month. Third, benchmark-adjusted returns are computed as the difference between the raw returns of company $i$ and the return on the benchmark portfolio over the same period.

$$
A R_{i t}=R_{i t}-R_{\text {bencht }}
$$

Fourth, the average benchmark-adjusted return $\overline{A R_{i t}}$ for month $t$ on a portfolio of $n$ stocks for event month $t$ is the value-weighted arithmetic mean of the benchmark adjusted returns:

$$
\overline{A R_{i t}}=\frac{1}{n} \sum_{i=1}^{n} A R_{i t}
$$


Finally, the cumulative average benchmark-adjusted returns from event month 1 to event month $t$ are defined by $\overline{C A R_{1, t}}$. This is calculated adding the average benchmark adjusted returns $\left(\overline{A R_{i t}}\right)$ over various intervals during the 36-month aftermarket period.

$$
\overline{C A R_{1, t}}=\sum_{t=1}^{t} \overline{A R_{i t}}
$$

To assess whether the cumulative average benchmark-adjusted returns are significantly different from zero, studentised $t$-tests for cumulative average benchmark adjusted returns are:

$$
C A R_{-} t_{\text {month }}=\frac{\overline{C A R_{1, t}}}{\sigma\left(C A R_{1, t}\right) / \sqrt{n}}
$$

where $\sigma$ is the sample standard deviation of abnormal returns and $n$ is the number of IPOs.

Buy-and-hold returns (BHRs)

The BHRs are from the following series. First, the buy-and-hold return for company $i$, denoted as $B H R_{i t}$, excluding the initial return on the first trading day, is defined as:

$$
B H R_{i t}=\left(\prod_{t=s t a r t}^{\min (T, \text { delist })}\left(1+R_{i t}\right)-1\right)
$$

Second, the benchmark buy-and-hold return, denoted as $B H R_{\text {bencht }}$, is calculated in the same manner:

$$
B H R_{\text {bencht }}=\left(\prod_{t=\text { start }}^{\min (T, \text { delist })}\left(1+R_{\text {bencht }}\right)-1\right)
$$

Third, the benchmark-adjusted buy-and-hold returns for each company, $B H A R_{i t}$, is calculated by deducting the buy-and-hold return for the company $i$ with the return of benchmark portfolio as follows:

$$
B H A R_{i t}=B H R_{i t}-B H R_{\text {bencht }}
$$

Fourth, the average buy-and-hold return for a period $t$, denoted as $\overline{B H A R}_{i t}$, is the arithmetic mean abnormal return on all IPOs in the sample of size $n$ : 


$$
\overline{B H A R}_{i t}=\frac{1}{n} \sum_{i=1}^{n} B H A R_{i t}
$$

Finally, the positive (negative) value of BHAR indicates that IPOs outperform (underperform) a portfolio of benchmarks. To test whether the average buy-and-hold return is different from zero for the sample of IPO, a $t$-test is calculated:

$$
B H A R_{-} t_{\text {month }}=\frac{\overline{B H A R}_{i t}}{\sigma\left(B H A R_{i t}\right) / \sqrt{n}}
$$

where $\sigma$ is the sample standard deviation of abnormal returns

Wealth relatives (WRs)

The final measure of IPO performance is the wealth relatives from the threeyear total buy-and-hold returns. We define these as the ratio of the end-of-period wealth from holding a portfolio of issuers to the end-of-period wealth from holding a portfolio of benchmarks, given by

$$
W R_{i t}=\frac{1+\overline{B H R_{i t}}}{1+\overline{B H R_{\text {bencht }}}}
$$

We can interpret a wealth relative of greater than unity as meaning that an IPO outperformed a portfolio of benchmarks, whereas a wealth relative of less than unity indicates that the IPO underperformed.

\subsection{Regression analysis}

Previous studies also suggest that the initial return and the issue size have a negative effect on long-run performance. For example, Ritter (1991) finds that there is the negative correlation between initial return and aftermarket performance while Allen et al. (1999) suggest that issue size has a negative effect on long-run returns. They also find that market return is likely to have positive relation with 2-year return. However, Ritter (1991) argues that age appears to be a better proxy for ex-ante uncertainty than issue size and concludes that younger IPOs have poorer aftermarket performance. Ritter (1991) also suggests there is a negative relation between volume and aftermarket performance due to the bad luck, overoptimistic forecasts or fads of investors. Therefore, to test the effects of issue size, initial return, annual volume, market returns, and industry (as a dummy variable to test IPOs performance across 
industry) on the three-year buy-and-hold return and three-year benchmark-adjusted buy-and-hold return, regression analyses clarify the effect of each factor. Unfortunately, firm age is poorly defined in the sample data and is not included in the analysis. The multiple regressions used are:

$$
\begin{aligned}
& 3 B H R_{i}=\beta_{0}+\beta_{1} R_{T N}+\beta_{2} S L E_{i}+\beta_{3} V O L_{i}+\beta_{4} M A R_{i}+\beta_{5} I N D_{i}+\varepsilon_{i} \\
& 3 B H A R_{i}=\beta_{0}+\beta_{1} R T N_{i}+\beta_{2} S L E_{i}+\beta_{3} V O L_{i}+\beta_{4} M A R_{i}+\beta_{5} I N D_{i}+\varepsilon_{i}
\end{aligned}
$$

where the dependent variables are the three-year buy-and-hold return $\left(3 B H R_{i}\right)$ and the three-year benchmark-adjusted buy-and-hold return $\left(3 B H A R_{t}\right)$. The explanatory variables are the monthly raw return excluding the initial return $(R T N)$, the issue size in millions of baht $(S L E)$, the number of IPOs each year $(V O L)$, the three-year benchmark buy-and-hold return for the market over the same period as the $I P O_{i}$ $(M A R)$ and various dummy variables (IND) for industry in which the $I P O_{i}$ operates.

\section{Empirical results}

\subsection{Underpricing}

Table 1 presents the headline underpricing (UPH), underpricing issuer loss (UPIL), underpricing loss by market value (UPLMV), and underpricing loss by issue price (UPLIP) measures for the sample of 136 IPOs listed on the SET from 19972007. Over the full sample period, $17.60 \%$ headline underpriced, $6.94 \%$ are issuer loss underpriced, 6.68\% are issuer price underpriced and $16.10 \%$ are market value loss underpriced. These results generally indicate that Thai IPOs are less underpriced than those in most developed markets are. However, there is substantial variability in the magnitude of underpricing over the sample period. For example, the yearly average headline underpricing between 1997 and 2000 is -20.39\% (overpriced), 1.44\%, 36.78\% (underprice), 14.86\%, 50.05\%, 14.05\%, 10.28\%, 1.45\%, and 26.42\%, respectively.

\section{$<$ TABLE 2 HERE $>$}

Table 2 provides average headline underpricing (UPH), underpricing issuer loss (UPIL), underpricing loss by market value (UPLMV), and underpricing loss by issue price (UPLIP) by industry. The results show that IPOs from the resource and financial 
industries are the most underpriced (38.09\% and 29.74\%, respectively) in terms of headline underpricing whereas IPOs in the industrial and consumer product industries are the least underpriced (2.00\% and $2.19 \%$, respectively). This contrast with earlier work by Allen et al (1999) that the property and construction industry has the highest initial IPO return of $215.09 \%$ among industries while the financial services industry (22.37\%) has the lowest.

\section{$<$ TABLE 3 HERE $>$}

\subsection{Aftermarket performance}

Figure 2 graphs the monthly average raw return, benchmark-adjusted return and cumulative benchmark-adjusted return for the 142 IPOs included in the sample up to 36 months. Most critically, the cumulative benchmark-adjusted return is above zero up until month 24 and then drops below zero for the remainder of the observation period. This suggests that Thai IPOs at first outperform the market benchmark, but their longer run performance is generally poor. Table 3 provides additional detail on the benchmark-adjusted returns and cumulative benchmark-adjusted returns.

\section{$<$ FIGURE 3 HERE $>$}

\section{$<$ TABLE 3 HERE $>$}

Table 4 reports the average buy-and-hold returns and wealth relatives, exclusive of the initial returns on the first day of trading up to 36 months after listing. The results show that IPO companies begin underperforming in terms of BHAR at the end of month 19 (an average of $-0.58 \%$ ), as also evidenced by a wealth relative less than unity (0.95\%). The 36-month average buy-and-hold return is $-25.39 \%$, with a statistical significant t-statistic of 4.30 . This is of considerably greater magnitude than the underperformance of IPOs found in the US by Ritter (1991) and Welch and Ritter (2002) and in Germany by Ljungqvist (1997) and Stehle et al (2000).

\section{$<$ TABLE 4 HERE $>$}

\subsection{Regression analysis}

Table 5 provides the regression estimates using the three-year buy-and-hold return as the dependent variable. These results suggest that there is a positive effect of monthly returns (RTN), as in Allen et al (1999), on three-year buy-and-hold returns. However, in contrast to Ritter (1991) and Allen and Patrick (1994), there is no 
significant negative relationship between issue size (SZE) and issue volume (VOL) on three-year buy-and-hold returns.

\section{$<$ TABLE 5 HERE $>$}

Table 7 presents the estimated results of a regression analysis using three-year benchmark-adjusted buy-and-hold returns as the dependent variable. The results again suggest the positive effect of monthly returns $(R T N)$ on three-year benchmarkadjusted buy-and-hold returns, while issue size (SZE), issue volume (VOL) and the market benchmark return (MAR) are insignificant. Combined together, these findings suggest that the post-listing performance of IPOs, at least in Thailand, relates to initial return $(R T N)$, but is not significantly related to either overall IPO activity (VOL), the size of the IPO (SZE), or the performance of the market (MAR).

\section{$<$ TABLE 6 HERE $>$}

Of the industry dummy variables in Tables 5 and 6, only the estimated coefficient for the financial services industry is significant and positive. This indicates that only companies in the financial services industry perform consistently better postlisting (excluding the initial return). This finding is similar to Allen et al (1999).

\section{Concluding remarks}

This paper examines the pricing and performance of initial public offerings on the main board of the Thai stock exchange from February 1997 to October 2008. Underpricing is calculated using headline underpricing, underpricing issuer loss, underpricing loss by market value, and underpricing loss by issuer price. Aftermarket performance is calculated using monthly cumulative abnormal returns, buy-and-hold returns and wealth relatives. Regression analysis is also used to control for other impacts on firm performance, including overall IPO activity, market performance and size effects, and to compare aftermarket performance across industries.

In term of underpricing, the results indicate that Thai IPOs are generally underpriced though the magnitude of underpricing is generally smaller than found in many developed markets using similar techniques. However, unlike many of these comparable studies, there is no evidence that IPO underpricing has decreased in the recent years. This is an important contribution of this paper, as it indicates that IPO pricing behaviour may differ substantially in emerging markets relative to developed markets. One suggestion is that investors in emerging markets are not as 
disproportionately informed as conventionally assumed. It also has important implications for the prospects of the owners of firms in suggesting that they may not be significantly disadvantaged in wealth terms when considering an IPO. The measures of underpricing across industry suggest that financial services IPOs are relatively more underpriced whereas industrial IPOs are relatively underpriced. This contrasts strongly with Allen et al. (1999) who find that the property and construction industry often has the highest initial return.

In term of performance, monthly cumulative abnormal and buy-and-hold returns and wealth relatives show that Thai IPOs underperform relative to the market at the end of a 36-month post-listing period. However, they generally outperform the market up to 24 months after listing. Regression analysis also provides evidence to support the notion that there is a significant positive relationship between monthly returns and buy-and-hold returns, even after controlling for size, volume, and activity in the IPO market. Further, financial services firms appear to display the best long-run performance in the Thai market. Once again, evidence that investors are not overly optimistic in this important particular market reinforces the notion that emerging markets may not be as informationally inefficient as conventionally believed.

\section{References}

Aggarwal, R., Leal, R., Hernanmdez, L., 1993. The aftermarket performance of initial public offerings in Latin America. Financial Management 22, 42-53.

Aggarwal, R., Pietra R., 1990. Fads in the initial public offering market? Financial Management 19, 45-57.

Allen, F., Faulhaber, G. R., 1989. Signaling by underpricing in the IPO market. Journal of Financial Economics 23, 303-323.

Allen, D.E., Morkel-Kingsbury, N.J., Piboonthanakiat, W., 1999. The long-run performance of initial public offerings in Thailand. Applied Financial Economics 9, 215-232.

Barber, B., Lyon, J., 1996. Detecting abnormal operating performance: The empirical power and specification of test statistics. Journal of Financial Economics 41, 359-399.

Bradley D.J., Jordan, B.D., 2002. Partial Adjustment to public information and IPO underpricing. Journal of Financial and Quantitative Analysis 37, 595-616.

Brav, A., Gompers, P.A., 1997. Myth or Reality? The long-run underperformance of initial public offerings: Evidence from venture and non-venture capital-backed companies. Journal of Finance 52, 1791-1821.

Brennan, M., Franks, J. ,1997. Underpricing, ownership and control in initial public offerings of equity securities in the United Kingdom. Journal of Financial Economics 45, 391-413.

Brooks, R., Dimovski, W., 2004. Initial public offerings in Australia 1994 to 1999: Recent evidence of underpricing and underperformance. Review of Quantitative Finance and Accounting 22, 179_ 198.

Bruner, R., Chaplinsky, S., Ramchand, L., 2006. Coming to America: IPOs from emerging market issuers. Emerging Markets Review 7, 191-212.

Carter, R., Dark, F., Singh, A., 1998. Underwriter reputation, initial returns, and the long-run performance of IPO stocks. Journal of Finance 53, 285-312.

Chang, E., Chen, C., Chi, J., 2008. IPO Underpricing in China: New evidence from the primary and secondary markets. Emerging Markets Review 9, 1-16. 
Ernst \& Young, 2006. Accelerating growth: Global IPO trends 2006. Available at http://www.ey.com/. Accessed May 2008.

Ernst \& Young, 2009. Q1's 09 global IPO update. Available at http://www.ey.com/ Accessed May 2009.

Francis, B.B., Hasan, I., 2001. The underpricing of venture and non venture capital IPOs: An empirical investigation. Journal of Financial Services Research 19, 99-113.

Habib, M.A., Ljungqvist, A.P., 1998. Underpricing and IPO proceeds: A note. Economic Letters 61, 381-383.

Habib, M.A., Ljungqvist, A.P., 2001. Underpricing and entrepreneurial wealth losses in IPOs: Theory and evidence. Review of Financial Studies 14, 433-458.

Hunt-McCool, J., Koh, S. C. and Francis, B. B., 1996, 'Testing for deliberate underpricing in the IPO premarket: A stochastic frontier approach’, Review of Financial Studies 9, pp. 1251-1269.

Ibbotson, R.G., Sindelar, J.L., Ritter, J.R., 1994. The market's problems with the pricing of initial public offerings. Journal of Applied Corporate Finance 7, 66-74.

Ibbotson, R.G., 1975. Price performance of common stock new issues. Journal of Financial Economics 2, 235-272.

Jain, B., Kimi, O., 1994. The post-issue operating performance of IPO firms. Journal of Finance 49, 1699-1726.

Kim, K., Kitsabunnarat, P., Nofsinger, J., 2004. Ownership and operating performance in an emerging market: Evidence from Thai IPO firms. Journal of Corporate Finance 10, 355-381.

Kothari, S.P., Warner, J.B., 1997. Measuring long-horizon security price performance. Journal of Financial Economics 43, 301-340.

Lee, P., Taylor, S., Walter, T., 1996. Australian IPO pricing in the short and long run. Journal of Banking and Finance 20, 1189-1210.

Lerner, J., 1994. Venture capitalists and the decision to go public. Journal of Financial Economics 35, 293-316.

Ljungqvist, A.P., Wilhelm, W. J., 2003. IPO pricing in the dot-com bubble. Journal of Finance 58, $723-752$.

Lonkani, R., 2000. Information acquisition and dissemination of the initial public offerings: The case of the Thai stock market. JDBA doctoral dissertation, Chulalonkorn University, Bangkok, Thailand.

Lonkani, R., Firth, M., 2005. The accuracy of IPO earnings forecasts in Thailand and their relationships with stock market valuation. Accounting and Business Research 35, 269-286.

Loughran, T., Ritter, J. R., 1995. The new issue puzzle. Journal of Finance 50, 23-51.

Loughran, T., Ritter, J., 2002. Why don’t issuers get upset about leaving money on the table in IPOs? Review of Financial Studies 15, 413-444.

Lyon, J. D., Barber, B. M., Tsai, C-L., 1999. Improved methods for testing of long run abnormal stock returns. Journal of Finance 54, 165-201.

Market for Alternative Investments 2009. Available at http://www.mai.or.th/. Accessed May 2009.

Megginson, W.L., Weiss, K.A., 1991. Venture capitalist certification in initial public offerings. Journal of Finance 46, 879-903.

Mikkelson, W., Partch, M., Shah, K., 1997. Ownership and operation performance of companies that go public. Journal of Financial Economics 44, 281-307.

Moonchul, K., Ritter, J. R., 1999. Valuing IPOs, Journal of Financial Economics 53, 409-437.

Ritter, J., 1991. The long run performance of initial public offerings. Journal of Finance 46, 3-28.

Rosa, R. S., Velayuthen, G., Walter, T., 2003. The sharemarket performance of Australian venture capital backed and non-venture capital backed IPOs. Pacific-Basin Finance Journal 11, 197-218.

Securities and Exchange Commission, 2000. Application for and approval of offer for sale of newly issued shares, Available at http://www.set.or.th/. Accessed October 2008.

Stock Exchange of Thailand, 2008. Listing manual for common shares in 2008, Available at http://www.sec.or.th/. Accessed May 2008.

Securities Exchange Commission, 2009. Available at http://www.sec.or.th/. Accessed May 2009.

Stock Exchange of Thailand, 2009a. Available at http://www.set.or.th/. Accessed May 2009.

Stock Exchange of Thailand, 2009b. Thailand's capital market in 2008, Accessed May 2009.

Stock Exchange of Thailand, 1997-2007. Fact Book, Available at http://www.set.or.th/. Accessed October 2008.

Wethayavivorn, K., Koo-Smith, Y., 1991. Initial public offerings in Thailand, 1988-1989: Price and return patterns. In S.G. Rhee, Chang R.P., (eds.), Pacific-Basin Capital Market Research, NorthHolland, Amsterdam, 379-394. 
World Federation of Exchanges, 2007, Annual Report and Statistics, Available at http://www.worldexchanges.org/. Accessed May 2009.

Zingales, L., 1995. Insiders' ownership and the decision to go public. Review of Economic Studies 62, 425-448. 
Figure 1

Number of newly listed and existing companies on the SET, 1975-2007

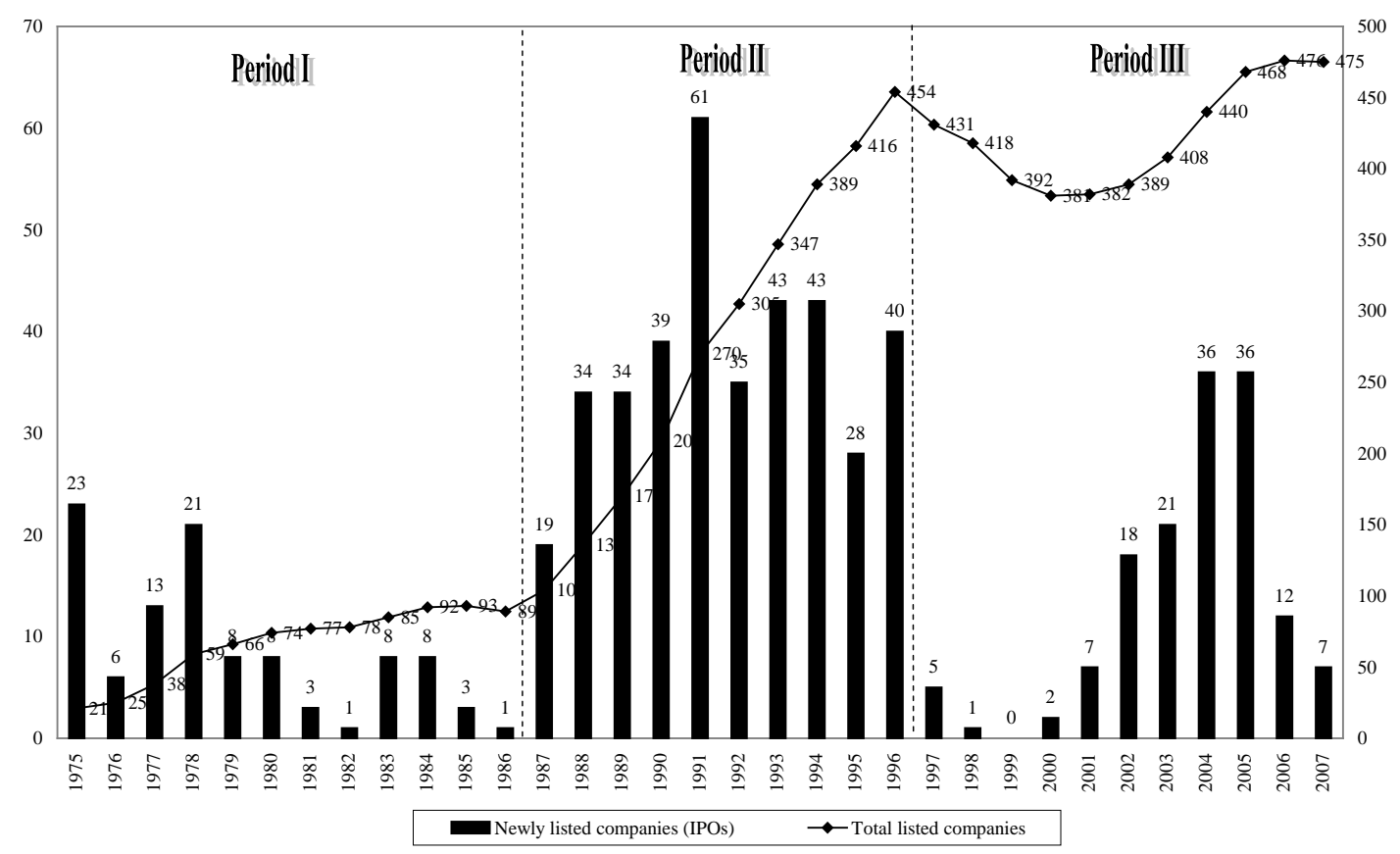

Table 1

IPO underpricing in percentages by year of issuance

\begin{tabular}{|c|c|c|c|c|c|}
\hline Year(s) & Statistic & UPH & UPIL & UPLMV & UPLIP \\
\hline \multirow[t]{6}{*}{ 1997-2007 (136) } & Mean & 17.6000 & 6.9400 & 6.6800 & 16.1000 \\
\hline & Median & 3.1000 & 1.4100 & 2.7500 & 2.8300 \\
\hline & Std dev. & 0.3780 & 0.1586 & 0.2556 & 0.3498 \\
\hline & $t$-statistic & 5.4308 & 5.1025 & 3.0466 & 5.3662 \\
\hline & $p$-value & 0.0000 & 0.0000 & 0.0028 & 0.0000 \\
\hline & Value-weighted & 7.1400 & 3.3100 & 1.1400 & 6.4400 \\
\hline \multirow[t]{6}{*}{1997 (4) } & Mean & -20.3900 & -11.3300 & -58.2800 & -18.8000 \\
\hline & Median & -31.5100 & -8.7700 & -58.2300 & -29.1100 \\
\hline & Std dev. & 0.4824 & 0.2101 & 0.7987 & 0.4296 \\
\hline & t-statistic & -0.8453 & -1.0784 & -1.4594 & -0.8754 \\
\hline & $p$-value & 0.4601 & 0.3598 & 0.2406 & 0.4458 \\
\hline & Value-weighted & -8.1300 & -7.4000 & -48.7100 & -8.1700 \\
\hline \multirow[t]{6}{*}{$2000(2)$} & Mean & -1.4400 & -2.7000 & -2.7000 & -1.5500 \\
\hline & Median & -1.4400 & -2.7000 & -2.7000 & -1.5500 \\
\hline & Std dev. & 0.1564 & 0.0925 & 0.1425 & 0.1362 \\
\hline & $t$-statistic & -0.1304 & -0.4126 & -0.2684 & -0.1610 \\
\hline & $p$-value & 0.9174 & 0.7509 & 0.8331 & 0.8983 \\
\hline & Value-weighted & 8.6000 & 3.2400 & 6.4400 & 7.1900 \\
\hline \multirow[t]{6}{*}{2001 (7) } & Mean & 36.7800 & 12.5700 & 15.3400 & 33.5300 \\
\hline & Median & 21.7100 & 7.1600 & 14.7200 & 17.9200 \\
\hline & Std dev. & 0.6148 & 0.1811 & 0.2505 & 0.5930 \\
\hline & $t$-statistic & 1.5830 & 1.8367 & 1.6206 & 1.4960 \\
\hline & $p$-value & 0.1645 & 0.1159 & 0.1562 & 0.1853 \\
\hline & Value-weighted & 6.3600 & 2.6300 & 2.9600 & 5.4800 \\
\hline \multirow[t]{3}{*}{2002 (16) } & Mean & 14.8600 & 6.7100 & 7.2700 & 13.2300 \\
\hline & Median & 0.7400 & 0.3900 & 0.6500 & 0.6500 \\
\hline & Std dev. & 0.3276 & 0.1640 & 0.1638 & 0.2915 \\
\hline
\end{tabular}




\begin{tabular}{|c|c|c|c|c|c|}
\hline Year(s) & Statistic & UPH & UPIL & UPLMV & UPLIP \\
\hline \multirow{8}{*}{2003 (19) } & $t$-statistic & 1.8148 & 1.6367 & 1.7739 & 1.8157 \\
\hline & $p$-value & 0.0896 & 0.1225 & 0.0964 & 0.0895 \\
\hline & Value-weighted & 9.3600 & 4.1200 & 5.3200 & 8.3900 \\
\hline & Mean & 50.0500 & 19.6100 & 24.3700 & 46.3800 \\
\hline & Median & 39.2900 & 14.0600 & 24.0400 & 32.0600 \\
\hline & Std dev. & 0.4553 & 0.1917 & 0.2479 & 0.4320 \\
\hline & $t$-statistic & 4.7915 & 4.4599 & 4.2858 & 4.6804 \\
\hline & $p$-value & 0.0001 & 0.0003 & 0.0004 & 0.0002 \\
\hline \multirow{3}{*}{2004 (36) } & Value-weighted & 60.1200 & 22.6700 & 28.9400 & 110.3200 \\
\hline & Mean & 14.0500 & 5.4500 & 6.2000 & 12.9600 \\
\hline & Median & 4.6200 & 1.5700 & 4.1900 & 4.4200 \\
\hline \multirow{9}{*}{2005 (34) } & Std dev. & 0.3197 & 0.1253 & 0.1977 & 0.2951 \\
\hline & $t$-statistic & 2.6371 & 2.6082 & 1.8824 & 2.6360 \\
\hline & $p$-value & 0.0124 & 0.0133 & 0.0681 & 0.0124 \\
\hline & Value-weighted & 9.5000 & 4.9300 & 2.4300 & 8.5300 \\
\hline & Mean & 10.2800 & 3.8200 & 5.1200 & 9.3900 \\
\hline & Median & 2.6000 & 0.5800 & 2.3400 & 2.3900 \\
\hline & Std dev. & 0.2431 & 0.0946 & 0.1640 & 0.2257 \\
\hline & $t$-statistic & 2.4662 & 2.3562 & 1.8192 & 2.4257 \\
\hline & $p$-value & 0.0190 & 0.0246 & 0.0780 & 0.0209 \\
\hline \multirow{4}{*}{2006 (11) } & Value-weighted & 7.3200 & 2.5900 & 3.2700 & 6.7200 \\
\hline & Mean & 1.4500 & 1.7800 & -0.1500 & 1.0700 \\
\hline & Median & -1.2500 & -0.3200 & -1.1900 & -1.1700 \\
\hline & Std dev. & 0.1352 & 0.0917 & 0.1025 & 0.1177 \\
\hline \multirow{9}{*}{2007 (6) } & $t$-statistic & 0.3552 & 0.6444 & -0.0493 & 0.3025 \\
\hline & $p$-value & 0.7298 & 0.5338 & 0.9617 & 0.7685 \\
\hline & Value-weighted & -7.7300 & -2.3100 & -9.0600 & -15.3900 \\
\hline & Mean & 26.4200 & 13.4200 & 10.3400 & 23.2800 \\
\hline & Median & 3.7300 & 1.1100 & 3.4500 & 3.5900 \\
\hline & Std dev. & 0.5910 & 0.3118 & 0.2089 & 0.5168 \\
\hline & $t$-statistic & 1.0948 & 1.0547 & 1.2127 & 1.1034 \\
\hline & $p$-value & 0.3235 & 0.3398 & 0.2794 & 0.3201 \\
\hline & Value-weighted & 12.8700 & 6.1900 & 5.9100 & 11.5500 \\
\hline
\end{tabular}

Notes: Number of IPOs in year/period in brackets. Statistics only provided where number of IPOs in year are greater than 1. UPH - headline underpricing, UPIL - underpricing issuer loss, UPLMV - underpricing loss by market value, and UPLIP - underpricing loss by issue price. $t$-statistics and $p$-values are tests of null hypothesis that means are equal to zero.

Table 2

IPO underpricing in percentages by industry

\begin{tabular}{clrrrr}
\hline \multicolumn{1}{c}{ Industry } & Underpricing & \multicolumn{1}{c}{ UPH } & \multicolumn{1}{c}{ UPIL } & UPLMV & UPLIP \\
\hline AGRO (4) & Mean & 2.9200 & 0.2400 & 2.4900 & 2.8500 \\
& Median & 1.4000 & 0.2400 & 2.4900 & 2.6800 \\
& Std dev. & 0.0572 & 0.0103 & 0.0507 & 0.0556 \\
& $t$-statistic & 1.0209 & 0.4550 & 0.9817 & 1.0272 \\
& $p$-value & 0.3825 & 0.6800 & 0.3986 & 0.3799 \\
& Value-weighted & 3.3800 & 0.4900 & 0.5600 & 0.0000 \\
CONSUMP (2) & Mean & -2.1900 & -0.3700 & -2.2100 & -2.1100 \\
& Median & -2.1900 & -0.3700 & -2.2100 & -2.1100 \\
& Std dev. & 0.0219 & 0.0037 & 0.0221 & 0.0211 \\
& $t$-statistic & -1.4142 & -1.4142 & -1.4142 & -1.4142 \\
& $p$-value & 0.3918 & 0.3918 & 0.3918 & 0.3918
\end{tabular}




\begin{tabular}{|c|c|c|c|c|c|}
\hline Industry & Underpricing & UPH & UPIL & UPLMV & UPLIP \\
\hline \multirow{3}{*}{ FINCIAL (21) } & Value-weighted & -1.8800 & -0.3200 & -1.8900 & -1.8100 \\
\hline & Mean & 29.7400 & 10.2700 & 14.5700 & 27.8600 \\
\hline & Median & 12.2700 & 3.0000 & 10.4000 & 11.6700 \\
\hline \multirow{9}{*}{ INDUS (18) } & Std dev. & 0.4717 & 0.1614 & 0.1985 & 0.4551 \\
\hline & $t$-statistic & 2.8896 & 2.9171 & 3.3640 & 2.8056 \\
\hline & $p$-value & 0.0091 & 0.0085 & 0.0031 & 0.0109 \\
\hline & Value-weighted & 40.5300 & 15.6400 & 21.2700 & 38.0800 \\
\hline & Mean & 2.0000 & -0.7800 & -9.8200 & 2.2200 \\
\hline & Median & -0.0100 & -0.1500 & -0.0400 & -0.0200 \\
\hline & Std dev. & 0.3238 & 0.1285 & 0.4383 & 0.3002 \\
\hline & $t$-statistic & 0.2626 & -0.2560 & -0.9502 & 0.3134 \\
\hline & $p$-value & 0.7960 & 0.8010 & 0.3553 & 0.7578 \\
\hline \multirow{3}{*}{ PROPCON (39) } & Value-weighted & 9.4200 & 2.6800 & 1.6500 & 8.9300 \\
\hline & Mean & 11.9700 & 4.8100 & 4.6300 & 10.6700 \\
\hline & Median & 2.2200 & 0.6000 & 2.0500 & 2.0900 \\
\hline \multirow{9}{*}{ RESOURC (11) } & Std dev. & 0.2997 & 0.1108 & 0.1904 & 0.2768 \\
\hline & t-statistic & 2.4946 & 2.7120 & 1.5187 & 2.4085 \\
\hline & $p$-value & 0.0171 & 0.0100 & 0.1371 & 0.0210 \\
\hline & Value-weighted & -4.4000 & -1.2500 & -8.1100 & -4.4600 \\
\hline & Mean & 38.0900 & 16.5700 & 21.2000 & 34.4800 \\
\hline & Median & 37.5000 & 11.5400 & 26.1300 & 36.6800 \\
\hline & Std dev. & 0.3310 & 0.1561 & 0.1631 & 0.2982 \\
\hline & t-statistic & 3.8174 & 3.5212 & 4.3119 & 3.8348 \\
\hline & $p$-value & 0.0034 & 0.0055 & 0.0015 & 0.0033 \\
\hline \multirow{4}{*}{ SERVICE (21) } & Value-weighted & 18.9200 & 8.8000 & 11.7700 & 17.6600 \\
\hline & Mean & 17.2400 & 8.8100 & 7.5300 & 15.3600 \\
\hline & Median & 3.1300 & 1.7200 & 2.7400 & 2.8200 \\
\hline & Std dev. & 0.3861 & 0.2089 & 0.1788 & 0.3396 \\
\hline \multirow{9}{*}{ TECH (20) } & $t$-statistic & 2.0467 & 1.9333 & 1.9311 & 2.0721 \\
\hline & $p$-value & 0.0541 & 0.0675 & 0.0678 & 0.0514 \\
\hline & Value-weighted & 6.0200 & 3.5400 & 1.7800 & 5.1800 \\
\hline & Mean & 23.9100 & 9.3500 & 10.0700 & 21.9500 \\
\hline & Median & 14.1300 & 5.4200 & 11.1800 & 12.8100 \\
\hline & Std dev. & 0.4063 & 0.1720 & 0.2482 & 0.3755 \\
\hline & t-statistic & 2.6313 & 2.4306 & 1.8138 & 2.6144 \\
\hline & $p$-value & 0.0164 & 0.0251 & 0.0855 & 0.0171 \\
\hline & Value-weighted & 17.1100 & 6.5900 & 8.0400 & 15.8100 \\
\hline
\end{tabular}

Notes: Number of IPOs in industry in brackets. Statistics only provided where number of IPOs in industry are greater than 1. UPH - headline underpricing, UPIL - underpricing issuer loss, UPLMV - underpricing loss by market value, and UPLIP - underpricing loss by issue price. AGRO - agricultural and food, CONSUMP - consumer products, FINCIAL - financial and banking, INDUS industrial, PROPCON - property and construction, RESOURC - resources, and TECH - technology. $t$-statistics and $p$-values are tests of null hypothesis that means are equal to zero. 
Figure 2

Average and benchmark-adjusted returns and cumulative benchmark-adjusted returns by post-IPO month

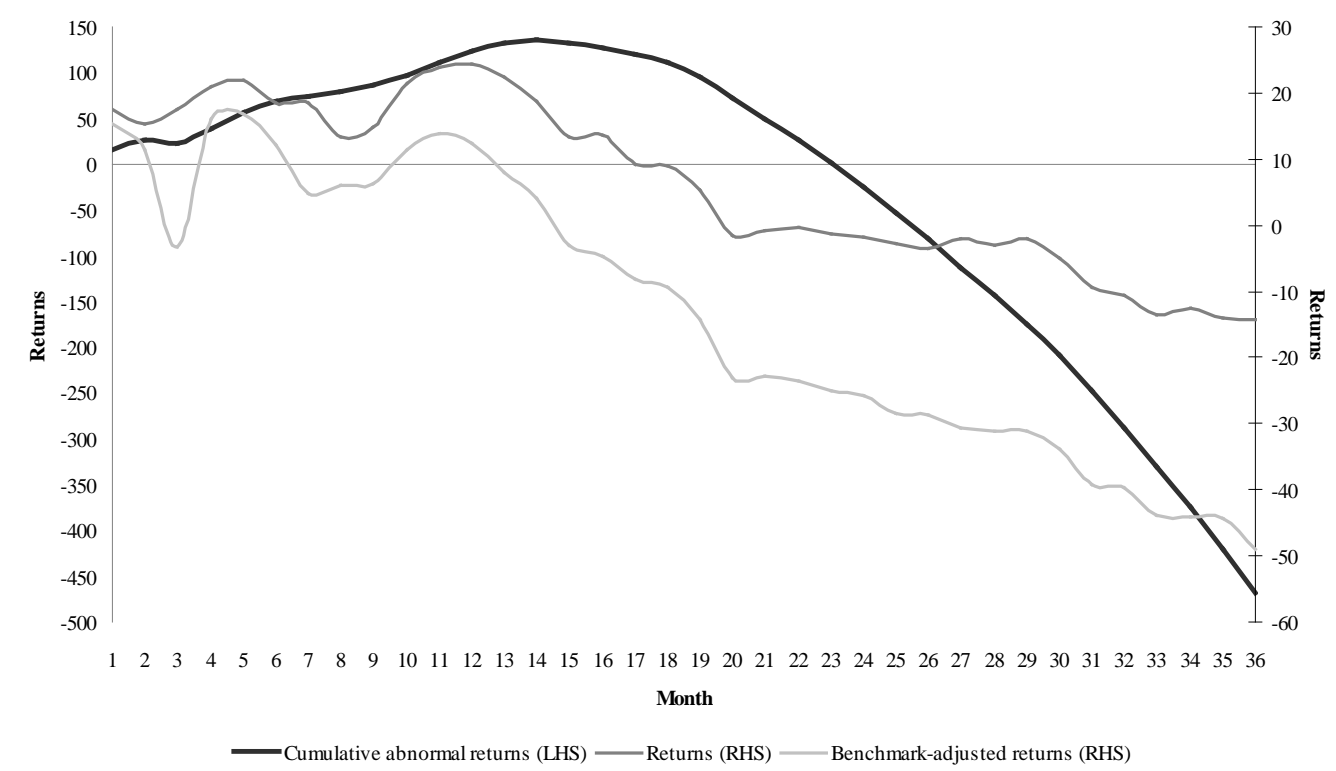

Note: Monthly returns are from the first full month of trading post-IPO to month 36, delisting or end of sample period.

Table 3

Average and cumulative benchmark-adjusted returns

\begin{tabular}{ccrcrrrrrr}
\hline Month & Size & $\overline{A R_{\text {it }}}$ & $\begin{array}{c}\text { Std } \\
\text { dev }\end{array}$ & \multicolumn{1}{c}{ t-stat } & p-value & $\overline{C A R_{1, t}}$ & Std dev & t-stat & p-value \\
\hline 1 & 141 & 15.4233 & 0.4699 & 3.8977 & 0.0002 & 15.4233 & 0.4699 & 3.8977 & 0.0002 \\
2 & 142 & 11.2980 & 0.5208 & 2.5853 & 0.0107 & 26.7213 & 0.5208 & 6.1146 & 0.0000 \\
3 & 142 & -3.3828 & 0.2895 & -1.3924 & 0.1660 & 23.3385 & 0.2895 & 9.6063 & 0.0000 \\
4 & 141 & 16.1578 & 0.6181 & 3.1038 & 0.0023 & 39.4962 & 0.6181 & 7.5871 & 0.0000 \\
5 & 141 & 16.8206 & 0.6348 & 3.1466 & 0.0020 & 56.3168 & 0.6348 & 10.5352 & 0.0000 \\
6 & 140 & 12.2686 & 0.6527 & 2.2242 & 0.0277 & 68.5855 & 0.6527 & 12.4340 & 0.0000 \\
7 & 140 & 4.8467 & 0.2701 & 2.1228 & 0.0355 & 73.4322 & 0.2701 & 32.1626 & 0.0000 \\
8 & 140 & 5.9452 & 0.7014 & 1.0029 & 0.3176 & 79.3774 & 0.7014 & 13.3904 & 0.0000 \\
9 & 141 & 6.3049 & 0.6690 & 1.1191 & 0.2650 & 85.6823 & 0.6690 & 15.2083 & 0.0000 \\
10 & 141 & 11.4923 & 0.8824 & 1.5465 & 0.1242 & 97.1746 & 0.8824 & 13.0768 & 0.0000 \\
11 & 141 & 13.8786 & 0.9380 & 1.7568 & 0.0811 & 111.0532 & 0.9380 & 14.0578 & 0.0000 \\
12 & 140 & 12.4859 & 0.9712 & 1.5211 & 0.1305 & 123.5391 & 0.9712 & 15.0502 & 0.0000 \\
13 & 138 & 7.9624 & 0.9975 & 0.9378 & 0.3500 & 131.5016 & 0.9975 & 15.4873 & 0.0000 \\
14 & 138 & 4.1818 & 0.9613 & 0.5110 & 0.6102 & 135.6834 & 0.9613 & 16.5809 & 0.0000 \\
15 & 138 & -3.1333 & 0.8892 & -0.4139 & 0.6796 & 132.5500 & 0.8892 & 17.5109 & 0.0000 \\
16 & 138 & -4.6754 & 0.9383 & -0.5853 & 0.5593 & 127.8747 & 0.9383 & 16.0090 & 0.0000 \\
17 & 136 & -8.0445 & 0.9194 & -1.0203 & 0.3094 & 119.8302 & 0.9194 & 15.1988 & 0.0000 \\
18 & 135 & -9.4629 & 0.9332 & -1.1782 & 0.2408 & 110.3673 & 0.9332 & 13.7420 & 0.0000 \\
19 & 134 & -14.3004 & 0.8552 & -1.9356 & 0.0550 & 96.0669 & 0.8552 & 13.0028 & 0.0000 \\
20 & 133 & -23.1636 & 0.8210 & -3.2538 & 0.0014 & 72.9032 & 0.8210 & 10.2407 & 0.0000 \\
21 & 131 & -22.9399 & 0.8106 & -3.2390 & 0.0015 & 49.9633 & 0.8106 & 7.0546 & 0.0000 \\
22 & 131 & -23.6046 & 0.8195 & -3.2969 & 0.0013 & 26.3587 & 0.8195 & 3.6815 & 0.0003 \\
23 & 131 & -25.0959 & 0.8488 & -3.3841 & 0.0009 & 1.2628 & 0.8488 & 0.1703 & 0.8651 \\
24 & 131 & -25.7713 & 0.8241 & -3.5793 & 0.0005 & -24.5084 & 0.8241 & -3.4039 & 0.0009 \\
25 & 131 & -28.4341 & 0.8566 & -3.7993 & 0.0002 & -52.9426 & 0.8566 & -7.0740 & 0.0000 \\
26 & 129 & -28.7524 & 0.9764 & -3.3445 & 0.0011 & -81.6950 & 0.9764 & -9.5027 & 0.0000
\end{tabular}




\begin{tabular}{cccccccccc}
\hline Month & Size & $\overline{A R_{i t}}$ & $\begin{array}{c}\text { Std } \\
\text { dev }\end{array}$ & t-stat & p-value & $\overline{C A R_{1, t}}$ & Std dev & t-stat & p-value \\
\hline 27 & 125 & -30.6071 & 0.9683 & -3.5338 & 0.0006 & -112.3021 & 0.9683 & -12.9662 & 0.0000 \\
28 & 125 & -31.0679 & 0.9183 & -3.7826 & 0.0002 & -143.3700 & 0.9183 & -17.4557 & 0.0000 \\
29 & 122 & -31.0791 & 0.9274 & -3.7014 & 0.0003 & -174.4491 & 0.9274 & -20.7761 & 0.0000 \\
30 & 123 & -33.9514 & 0.8834 & -4.2625 & 0.0000 & -208.4005 & 0.8834 & -26.1640 & 0.0000 \\
31 & 121 & -39.3282 & 0.8417 & -5.1398 & 0.0000 & -247.7287 & 0.8417 & -32.3755 & 0.0000 \\
32 & 121 & -39.6383 & 0.8616 & -5.0607 & 0.0000 & -287.3670 & 0.8616 & -36.6890 & 0.0000 \\
33 & 119 & -43.9016 & 0.8226 & -5.8219 & 0.0000 & -331.2686 & 0.8226 & -43.9306 & 0.0000 \\
34 & 119 & -44.1491 & 0.8712 & -5.5284 & 0.0000 & -375.4177 & 0.8712 & -47.0101 & 0.0000 \\
35 & 119 & -44.2813 & 0.8744 & -5.5245 & 0.0000 & -419.6991 & 0.8744 & -52.3617 & 0.0000 \\
36 & 110 & -49.1124 & 0.8472 & -6.0803 & 0.0000 & -468.8115 & 0.8472 & -58.0402 & 0.0000 \\
\hline
\end{tabular}

Table 4

Average buy-and-hold returns and wealth relatives excluding initial return

\begin{tabular}{ccccccc}
\hline Month & Size & $\overline{\text { BHAR }}$ & Std. dev & t-stat & p-value & WR $_{\text {it }}$ \\
\hline 1 & 141 & 15.4233 & 0.4699 & 3.8977 & 0.0002 & 6.1368 \\
2 & 142 & 12.5950 & 0.4756 & 3.1556 & 0.0020 & 4.1855 \\
3 & 142 & 11.8892 & 0.4869 & 2.9098 & 0.0042 & 3.4796 \\
4 & 141 & 12.6104 & 0.4966 & 3.0156 & 0.0030 & 3.6130 \\
5 & 141 & 12.9219 & 0.5106 & 3.0048 & 0.0031 & 3.5682 \\
6 & 140 & 12.4124 & 0.5211 & 2.8181 & 0.0055 & 3.2801 \\
7 & 140 & 11.7535 & 0.5323 & 2.6124 & 0.0100 & 3.0596 \\
8 & 140 & 10.4675 & 0.5391 & 2.2973 & 0.0231 & 2.7502 \\
9 & 141 & 9.3317 & 0.5396 & 2.0534 & 0.0419 & 2.4704 \\
10 & 141 & 8.8202 & 0.5514 & 1.8993 & 0.0596 & 2.3155 \\
11 & 141 & 8.5515 & 0.5613 & 1.8091 & 0.0726 & 2.2651 \\
12 & 140 & 8.1388 & 0.5723 & 1.6828 & 0.0947 & 2.1201 \\
13 & 138 & -8.4137 & 1.2563 & -0.7867 & 0.4328 & 1.1512 \\
14 & 138 & 5.4494 & 0.5805 & 1.1028 & 0.2720 & 1.6376 \\
15 & 138 & 4.1183 & 0.5831 & 0.8296 & 0.4082 & 1.4569 \\
16 & 138 & 2.7027 & 0.5881 & 0.5399 & 0.5902 & 1.2773 \\
17 & 136 & 1.7799 & 0.5950 & 0.3488 & 0.7278 & 1.1826 \\
18 & 135 & 0.6544 & 0.6005 & 0.1266 & 0.8994 & 1.0639 \\
19 & 134 & -0.5848 & 0.6050 & -0.1119 & 0.9111 & 0.9456 \\
20 & 133 & -3.1628 & 0.6150 & -0.5931 & 0.5541 & 0.7184 \\
21 & 131 & -3.9676 & 0.6073 & -0.7478 & 0.4559 & 0.6561 \\
22 & 131 & -5.3648 & 0.6064 & -1.0126 & 0.3131 & 0.5545 \\
23 & 131 & -6.7777 & 0.6071 & -1.2779 & 0.2036 & 0.4586 \\
24 & 131 & -8.1023 & 0.6076 & -1.5262 & 0.1294 & 0.3746 \\
25 & 131 & -9.2451 & 0.6084 & -1.7392 & 0.0844 & 0.3157 \\
26 & 129 & -11.3410 & 0.6105 & -2.1100 & 0.0368 & 0.1864 \\
27 & 125 & -12.1316 & 0.6227 & -2.1782 & 0.0313 & 0.1833 \\
28 & 125 & -13.6655 & 0.6245 & -2.4465 & 0.0158 & 0.0905 \\
29 & 122 & -15.2922 & 0.6332 & -2.6674 & 0.0087 & 0.0227 \\
30 & 123 & -15.7789 & 0.6358 & -2.7523 & 0.0068 & 0.0204 \\
31 & 121 & -17.3464 & 0.6378 & -2.9918 & 0.0034 & -0.0294 \\
32 & 121 & -18.3996 & 0.6363 & -3.1811 & 0.0019 & -0.0798 \\
33 & 119 & -19.6274 & 0.6340 & -3.3773 & 0.0010 & -0.1116 \\
34 & 119 & -20.9393 & 0.6279 & -3.6381 & 0.0004 & -0.1559 \\
35 & 119 & -21.7356 & 0.6227 & -3.8077 & 0.0002 & -0.1757 \\
36 & 110 & -25.3903 & 0.6198 & -4.2966 & 0.0000 & -0.3037 \\
\hline & & & & & & \\
\hline
\end{tabular}


Table 5

Multiple regression estimates

\begin{tabular}{lcccc}
\hline & $\begin{array}{c}\text { Estimated } \\
\text { coefficient }\end{array}$ & $\begin{array}{c}\text { Standard } \\
\text { error }\end{array}$ & t-statistic & p-value \\
\hline Constant & 0.0237 & 0.1639 & 0.1444 & 0.8855 \\
RTN & $\mathbf{0 . 5 9 2 4}$ & $\mathbf{0 . 0 6 1 0}$ & $\mathbf{9 . 7 1 0 6}$ & $\mathbf{0 . 0 0 0 0}$ \\
SZE & -0.0007 & 0.0004 & -1.6040 & 0.1119 \\
VOL & -0.0014 & 0.0041 & -0.3284 & 0.7433 \\
MAR & 0.1817 & 0.1999 & 0.9088 & 0.3656 \\
AGRO & -0.1762 & 0.2471 & -0.7132 & 0.4774 \\
FINCIAL & $\mathbf{0 . 2 4 8 4}$ & $\mathbf{0 . 1 3 1 0}$ & $\mathbf{1 . 8 9 6 3}$ & $\mathbf{0 . 0 6 0 8}$ \\
INDUS & -0.0209 & 0.1382 & -0.1512 & 0.8801 \\
RESOURC & -0.0693 & 0.1754 & -0.3950 & 0.6937 \\
SERVICE & -0.0667 & 0.1333 & -0.5002 & 0.6181 \\
TECH & 0.0731 & 0.1356 & 0.5395 & 0.5908 \\
\hline
\end{tabular}

Notes: Dependent variable is three-year buy-and-hold returns (3BHR). Industry dummies are agricultural and food (AGRO), financial and banking industry (FINCIAL), industrial (INDUS), resources (RESOURC), services (SERVICE) and technology (TECH). Consumer products (CONSUMP) have only a single IPO and are excluded. Coefficient of property and construction $(\mathrm{PROPCON})$ excluded due to tolerance $=0.000$ [tolerance $=1-\mathrm{R}^{2}$ or (correlation between the predictor and all other predictors) $\left.{ }^{2}\right]$.

Table 6

Multiple regression estimates

\begin{tabular}{lcccc}
\hline & $\begin{array}{c}\text { Estimated } \\
\text { coefficient }\end{array}$ & $\begin{array}{c}\text { Standard } \\
\text { error }\end{array}$ & t-statistic & p-value \\
\hline Constant & 0.0237 & 0.1639 & 0.1444 & 0.8855 \\
RTN & $\mathbf{0 . 5 9 2 4}$ & $\mathbf{0 . 0 6 1 0}$ & $\mathbf{9 . 7 1 0 6}$ & $\mathbf{0 . 0 0 0 0}$ \\
SZE & -0.0007 & 0.0004 & -1.6040 & 0.1119 \\
VOL & -0.0014 & 0.0041 & -0.3284 & 0.7433 \\
MAR & $\mathbf{- 0 . 8 1 8 3}$ & $\mathbf{0 . 1 9 9 9}$ & $\mathbf{- 4 . 0 9 4 2}$ & $\mathbf{0 . 0 0 0 1}$ \\
AGRO & -0.1762 & 0.2471 & -0.7132 & 0.4774 \\
FINCIAL & $\mathbf{0 . 2 4 8 4}$ & $\mathbf{0 . 1 3 1 0}$ & $\mathbf{1 . 8 9 6 3}$ & $\mathbf{0 . 0 6 0 8}$ \\
INDUS & -0.0209 & 0.1382 & -0.1512 & 0.8801 \\
RESOURC & -0.0693 & 0.1754 & -0.3950 & 0.6937 \\
SERVICE & -0.0667 & 0.1333 & -0.5002 & 0.6181 \\
TECH & 0.0731 & 0.1356 & 0.5395 & 0.5908 \\
\hline
\end{tabular}

Notes: Dependent variable is three-year benchmark-adjusted buyand-hold returns (3BHAR). Industry dummies are agricultural and food (AGRO), financial and banking industry (FINCIAL), industrial (INDUS), property and construction (PROPCON), resources (RESOURC), services (SERVICE) and technology (TECH). Consumer products (CONSUMP) have only a single IPO and are excluded. Coefficient of property and construction $(\mathrm{PROPCON})$ excluded due to tolerance $=0.000$ [tolerance $=1-\mathrm{R}^{2}$ or (correlation between the predictor and all other predictors) $\left.{ }^{2}\right]$. 